\title{
토포필리아의 학습동기 역할 사례와 교육자원 분석 The case study of Topophilia's Role as a Motivator to Learn and an Analysis of Educational Resources
}

\author{
윤마병 \\ 전주대학교 과학교육과 \\ Ma-Byong Yoon(mabyong@hanmail.net)
}

\section{요약}

토포필리아는 어린 시절에 경험한 아름답고 행복한 낙원으로서의 고향에 대한 애착이나 그리움의 정서적 유대감을 말한다. 고향에서 경험한 기억들은 짧지만 강렬하여 학습과 의미 부여의 과정을 통해 긍정적인 정서를 갖는 토포필리아로 작용하여 학습동기가 될 수 있다. 정주영의 성공 스토리와 드보르작에 관한 기록 연구 결과, 정주영에게 소와 고향은 토포필리아의 주된 구체물이며 장소로서 성공의 원동력이 되었다. 드보 르작도 고향에 대한 그리움을 기차 소리의 공감각으로 승화시켜 음악으로 완성했다. 자연에서도 일출과 일 몰, 계절의 변화, 심장박동 등과 같이 다양한 리듬의 존재를 찾을 수 있는데 이러한 리듬 위에 멜로디가 들어가면 예술이 되고, 조화와 원리를 찾다보면 과학이 된다. 토포필리아를 함양할 수 있는 교육자원으로서 전북지역의 자연과 장소, 음식, 예술 분야를 분석했다. 전주 한옥마을에서 장소의 리추얼을 체험하게 하고, 고추장의 가치를 찾으며 고향의 구체물로서 마이산과 화가 최북을 제안한다.

\section{- 중심어 : | 토포필리아 | 교육자원 | 학습동기 | 긍정적 정서 |}

\section{Abstract}

Topophilia refers to emotional bonding such as attachment to or nostalgia for one's home town, which is remembered or imagined as a beautiful and happy paradise experienced in youth. The time spent in one's home town may have been short, but the associated memories of it are strong and enduring. These can later act as a strong motivator to learn if the correlated emotions are positive. According to archival research conducted on Jooyoung Chung's life, his home town and the things found therein, such as cows, were the principal objects of his topophilia, and later became the driving forces behind his success story. The same applies to Dvorak. Dvorak sublimated his nostalgia for his home town by composing a piece of music on hearing the sound of a train. We can discover diverse rhythms in nature such as sunrises and sunsets, the changing seasons, and even our heart beat. If a melody is added to the rhythm, it transforms into art. And if we seek harmony and principles, it becomes science. In this study, Jeonbuk's nature, places, food, and arts, as represented in its educational resources, are analysed for their ability to give rise to topophilia. To gain some experience of this feeling we recommend that you visit the Jeonju Hanok Village, the value of Gochujang, reverse icespike on Mai Mountain or enjoy the works of the painter Book Choi.

- keyword : I Topophilia I Educational Resource I Motivation to Learn I Positive Emotion I

\footnotetext{
* 이 논문은 2013년도 정부(과학기술진흥기금/복권기금)의 재원으로 한국과학창의재단의 지원에 의하여 연구되었음(2013상 반기과제-48) 


\section{I. 서 론}

인간에게 기억은 이성적이고 정서적인 힘의 원천이 면서 자기를 인식하는 준거점을 이룬다. 기억을 구성하 는 여러 요소들 가운데에서 가장 광범위하고 본질적인 것으로 '장소(place 또는 topos)'를 주목할 수 있다[26]. 장소는 그 자체만으로도 기억의 주된 초점이 될 수 있 지만 기억의 또 다른 구성 요소인 인물이나 사건 등의 배경적 토대와 함께 추억으로 존재한다[27]. 김소월의 시 '엄마야 누나야 강변 살자'를 들을 때 마다 어린 시절 에 뛰놀던 뒷동산과 금 모래 빛 강변의 추억과 함께 친 구들과의 아름다운 시절이 떠오르게 된다. 과거에 경험 했던 어떤 장소가 기억 속에 주된 초점으로 떠오르고 긍정적 정서로 남을 수 있는 것은 그 장소가 행복한 낙 원의 형태로 강한 애착과 그리움을 갖추고 있을 때이 다. 이것을 토포필리아(topophilia)라고 하는데 영원히 돌아오지 않을 잃어버린 시공간으로서 유년 시절의 아 름답고 행복한 고향에 대해 우리가 갖는 애착이나 그리 움의 정서적 유대감을 말한다[26]. 즉 토포필리아는 자 연에 대한 어린 시절의 좋은 경험이 기억과 학습, 의미 부여 등을 통하여 형성된 하나의 경관 이미지라고 할 수 있다. 토포스(topos)는 그리스어로 '장소, 곳, 땅'을 뜻하며, 필리아(philia)는 '애착, 사랑, 애호'를 의미하므 로 토포필리아는 개인적이고 심오한 인상과 의미를 갖 는 장소에 대한 만남, 즉 장소애를 의미한다. 유아기 아 동은 행동의 반경을 넓혀가면서 주변의 환경을 탐색하 여 낮설고 위협적인 공간(space)을 익숙하고 안전한 장 소(place)로 만들어 가는 과정에서 장소에 대한 애착이 최초로 발생한다. 이러한 장소 사랑의 본능적 뿌리 내 림은 자기가 속한 장소에 대한 의미와 가치 부여를 통 해 토포필리아로 완성될 수 있다[1].

일상에서 반복되는 행동 패턴인 리추얼(ritual)은 과 거에 경험한 구체물에 대한 기억들이 일정한 정서적 반 응과 의미부여 과정이 동반되어 성인이 되어서도 긍정 적인 정서로 의식되는 것을 말한다[2]. 고향과 장소, 공 간에 대한 어린 시절의 기억에 의미가 부여되고, 긍정 적인 정서로서 리추얼이 작용할 때 토포필리아가 형성 될 수 있다. 어린 시절에 경험했던 고향의 시공간에 대
한 그리움과 애착은 인간 공통의 감성이다[27]. 현대와 같이 장소성이 약화된 문화적 조건 속에서는 장소 감각 이나 공간 정서인 토포필리아가 형성될 가능성이 점차 적어지고 있다. 이러한 양상은 현대사회에서 하나의 뿌 리에 정착하지 못하고 삶의 거점을 여러 곳에 두고 옮 겨 다니는 신유목민(노마드)적 삶을 살아가는 사람들에 게 잘 나타나고 있어서[3], 청소년들에게 전형화 된 예 전의 고향이나 장소로서의 집과 같은 공간을 체험할 수 있는 기회를 더욱 제공해야 한다. 이에 학습자의 학습 동기와 인지과정에 강한 영향을 주는 긍정적 정서를 향 상시킬 수 있는 연구가 필요하다. 미래 과학교육에 관 한 $\mathrm{OECD}[28]$ 보고에서도 정서적 능력이 인지과정에 미치는 영향이 크기 때문에 학교에서 긍정적 정서를 향 상시키는 노력이 중요하다고 제시하고 있다.

본 연구에서는 어린 시절에 형성된 토포필리아의 긍 정적 정서와 동기가 성공의 원동력 또는 예술혼으로 작 용했던 사례를 분석하고, 학생들에게 학습동기 역할을 할 수 있는 토포필리아의 교육자원을 제안하고자 한다. 본 연구의 연구문제는 다음과 같다.

1. 어린 시절에 형성된 토포필리아가 어떻게 성공의 원동력 또는 예술의 혼으로 작용하는가?

2. 전북 지역의 교육자원을 활용하여 과학 체험활동 으로 토포필리아를 함양할 수 있는 학습소재는 무 엇인가?

\section{II. 학습동기로서의 토포필리아}

정서 또는 감성(emotion)은 다차원적인 것으로 자극 에 대한 경험과 생리적인 반응 성향을 포함하는 목적 지향적인 사회적 현상이라고 할 수 있다[29][30]. 특히 긍정적인 정서는 환경적 자극에 대해 긍정적인 평가를 하는 의식 상태로서 의미부여라는 인지적 평가가 중요 하게 작용한다. 그래서 긍정적 정서는 외적인 자극 없 이도 발생할 수 있으며[31], 인간의 삶에 미치는 영향이 매우 크다[32][33]. 어린 시절 자연과 경관에서 얻어지 는 긍정적 정서의 경험은 일시적 효과뿐만 아니라, 지 속적으로도 긍정적인 효과를 가져올 수 있다. 긍정적 
정서 상태에 있는 사람들이 중립적인 기분과 정서를 갖 고 있는 사람들보다 다른 사람을 더 잘 도와주고, 더 협 력적으로 행동하는 것으로 알려져 있다[34-36]. 또한 실패를 더 잘 견디어 내고[37], 더 창의적이며 합리적인 의사결정을 하며, 더욱 높은 내재적 동기를 나타낸다 [38]. 이러한 긍정적인 정서는 건강과 직업, 결혼 등에 서도 성공적인 영향력으로 발휘된다[4]. 학습과 관련하 여 긍정적인 정서는 일시적이지만 시각과 청각 주의력 을 확장시키고[39][40], 새로운 경험에 대한 개방성을 증가시킨다[41]. 장기적으로도 긍정적 정서는 학습역량 과 지적 자원을 형성하여 창의력과 사고 패턴 및 뇌의 발달을 촉진하며 과거의 경험과 지식을 토대로 신속한 문제해결 능력, 창조적인 정보 처리 능력을 보인다 [38][42][43].

동기의 관여와 만족은 긍정적 정서들을 통합함으로 서 이루어지는데 동기 만족이 있을 때 즐거움이 생기 고, 기쁨은 흥미를 증가시키며 또 다른 흥미와 관심들 을 대치시킴으로서[30][44] 특정 활동과 학습과제에 대 해서 자발적으로 참여할 수 있도록 하는 중요한 요인이 다. 특히 학습 상황에서 긍정적 정서는 학습동기에 큰 역할을 함으로서 기억과 언어 능력, 유연한 사고, 문제 해결력과 사회적 상호작용의 향상에 기여한다[45]. 그 러므로 효과적인 교수-학습은 긍정적 정서를 매개로 형성된 학습동기가 매우 중요한 역할을 한다[5][6]. 학 습자에게는 학습의 주체가 되고자 하는 의도적인 노력 [46]이 필요하며 메타인지와 높은 학업 성취를 이루고 자 하는 학습자의 목표 지향적인 행동이 요구된다 [47][48]. 학습자가 학습 환경에서 자기주도적으로 학습 할 수 있는 능력과 학습동기의 정도에 따라 학업 성취 과정과 그 결과는 다르게 나타날 수 있다. 그러므로 교 사는 학업수행에 관한 학습동기 뿐만 아니라 자기주도 적인 학습 전략을 구사할 수 있는 긍정적이고 적극적인 태도를 지녀야 한다[7][8]. 성공적인 학습을 위해서는 학생들도 스스로 학습을 하고자하는 동기를 부여하여 학습 상황을 조절하고 학습목표에 도달하기 위하여 그 에 적합한 자기만의 전략을 활용할 수 있어야 한다[9].

Tuan(1961)은 인간이 자신의 주변 세계를 거주 가능 한 장소로 구조화하고자 하는 본능적인 성향을 토포필
리아라고 하면서 안전과 안정의 정서를 포함하는 장소 (place)와 개방과 자유, 위협의 정서와 결합하는 공간 (space)을 구별했다[26]. 장소는 집처럼 편안함을 느낄 수 있는 정감(feel at home)의 연장선에 있는 것으로서 삶의 근거인 집과 근처의 땅, 지형 등에서 오랫동안 이 어져 온 밀착된 정서를 포함한다[10]. 장소가 실제 거주 하였던 정지된 곳이라면, 공간은 행복한 장소의 이미지 들을 포함하는 것으로서 움직임이 일어나는 곳이라고 할 수 있다[11]. 즉 장소는 물리적 구획의 지표나 경계 의 표지가 없는 구성적 개념으로서 인간의 지각과 경 험, 교육 등을 통해 공간을 장소화하는 근간이 될 수 있 다[3]. 이러한 장소와 공간의 이미지를 담고 있는 토포 필리아는 어떤 장소를 대면하거나 경험하는 순간 그 즉 시 발생하는 정서라기보다는 시간이 지남에 따라 그 장 소의 특별한 의미와 가치를 인식하게 되는 과정에서 점 진적으로 발생, 축적되는 정서이다. 그러므로 토포필리 아는 주로 의미와 가치를 부여한 회상이나 학습 등이 아름다운 추억의 기억들로 이루어진다. 유년시절에 경 험했던 장소와 고향에 대한 향수는 그 자체로 정서적인 유대 및 결속을 함축하고 있으며 애틋한 그리움의 공간 인 동시에 희망의 공간으로서 토포필리아의 전형이라 고 할 수 있다.

토포필리아는 시간적으로나 공간적으로 그 대상과 멀리 떨어져 있을 때 기억 또는 회상을 매개로 하여 재 현될 수 있다[26]. 학습자가 자신이 머물고 있었던 환경 에 대해 남다른 의미를 부여하는 일은 그 자체로서 사 후적인 현상에 속한다. 그렇기 때문에 토포필리아를 재 현하거나 학습동기로서 역할을 하고자 할 때는 공간과 장소, 경관과 결부된 추억의 현장으로 거슬러 올라가 승화된 긍정적 정서를 표출시킬 수 있어야 한다. 즉 학 생들에게 사람과 장소 또는 고향 등 시공간에 대한 다 양한 정서적 유대감을 형성하고 물질적인 자연환경에 서 정서적으로 리추얼할 수 있는 토포필리아를 계발시 켜야 한다. 급변하는 현대 사회에서 한 지역에 정착하 지 못하고 노마드적으로 살아가는 학생들에게 청소년 시절을 보내고 있는 그들의 도시와 지역, 자연과 경관 을 교육자원으로 활용하여 다양한 공감각 활동을 통해 토포필리아를 구성하는 리추얼로 자리 잡을 수 있도록 해야 한다. 자연에 대한 미학적인 쾌감과 감성적인 체 
험은 격렬하지만 순간적이어서 과학적 호기심이나 관 심 등과 결합해야 빨리 사라지지 않고 오랫동안 지속되 며 긍정적인 정서로 자리 잡을 수 있게 된다. 어린 아 동들은 정신과 마음이 열려 있어서 다른 사람에게 주의 를 기울이지 않고 공인된 미적 규범에 관심이 없기 때 문에 매력적인 자신 만의 감각이 작동될 수 있다[26]. 특히 학생 시절에 갖는 자유 시간, 즉 아무것도 하지 않 고 자신만의 여가 시간을 갖을 때 비로소 자신의 잠재 력을 깨달을 수 있다[49]. 'school'은 여가를 뜻하는 그 리스어 'scholea'에서 나온 것으로 자유롭게 생각할 수 있는 여유의 시간을 가장 잘 활용할 수 있는 곳이 학교 라는 것이다. 학생들에게 한가하게 누워 파란 하늘과 흘 러가는 구름을 바라보며 시간과 공간, 생각의 여유 속에 서 여러 냄새와 대지의 따스함, 견고하면서도 부드러운 자연의 윤곽선, 흐르는 물소리 등을 감성적으로 체험할 수 있는 기회를 제공해야 한다. 이러한 환경은 듣기 좋 은 음조와 미학의 공식적 규칙에 부합되지는 않지만, 세 월이 지나 어른이 되었을 때 아득한 추억과 긍정적인 감 성으로 자리 잡게 되고, 토포필리아로 작용하여 삶의 원 동력이자 학습동기 역할을 할 수 있을 것이다.

\section{III. 연구 방법}

\section{1. 연구 대상}

본 연구는 어린 시절에 형성된 토포필리아가 성공의 원동력 또는 예술의 혼으로 작용하는 사례를 분석하기 위해 아산 정주영의 성공 스토리와 드보르작의 '유모레 스크'를 분석 대상으로 했다. 또한 청소년들에게 토포필 리아를 함양하여 학습동기 역할을 할 수 있도록 하는 교육자원과 학습 소재 분석을 위해 전북지역 중등학교 과학교사와 교육 전문가 10 인을 대상으로 인터뷰와 설 문을 조사했다. 이들은 토포필리아의 과학교육 역할을 잘 이해하고 있으며 체험활동 지도에도 적극 참여하고 있는 전문가들이다.

\section{2. 연구방법 및 자료수집}

정주영 회장의 경영철학과 의사결정 과정, 드보르작 의 '유모레스크'에는 토포필리아가 어떤 역할을 하고 있
는가를 알아보기 위해 기록연구(archival research) 방 법을 사용했다. 이미 고인이 된 정주영과 드보르작을 대상으로 의문에 대한 답을 찾는 것은 많은 제약과 어 려움을 가지고 있다. 이러한 한계점을 극복하고자 연구 대상에 대한 직접적인 자료 수집이 불가능할 때 주로 사용되는 기록연구를 통해 그 근거를 찾았다. 개인을 대상으로 하는 기록연구에서는 연설문과 회고록, 자서 전, 대담 등이 자료원으로 사용된다. 기록연구는 크게 두 가지 분석 방법을 사용하는데 하나는 기록된 문구에 대한 정성적 분석으로 핵심적인 문구를 찾아 이를 해석 하는 것이고, 또 하나는 정량적 분석으로 핵심 문구나 단어에 관심을 갖고 이를 빈도 등으로 정량화하는 것이 다[50]. 정성적 분석은 분석 대상에 대한 깊이 있는 해 석을 가능하게 하고, 정량적 분석은 그것에 객관성을 부여함으로서 두 방법은 서로 상보적인 관계를 갖는다. 정주영에 관한 기록연구 분석에는 그의 회고록 '시련은 있어도 실패는 없다[12]'와 직접적인 화법으로 인용된 연설이나 대담, 글 등의 언행록을 자료원으로 사용했다. 드보르작의 경우에는 관련 논문과 그의 작품 등을 분석 하여 토포필리아와의 관련성을 찾았다. 드보르작이 어 린 시절에 들었던 기차소리와 그의 작품 '유모레스크'의 파형 분석을 위해 음향 분석 프로그램인 ‘Cool edit pro 2.1 '을 사용했다.

전북 지역의 자연과 전통 및 예술 등에서 학생들에게 토포필리아를 형성할 수 있는 교육자원을 분석하기 위 해 전북지역의 중등과학교사 7 인과 과학교육 전공 교 수 및 전문가 3 인에게 설문조사와 인터뷰를 실시했다. 검사도구 문항은 리커드 척도(5단계)를 통하여 개인적 경험에 비추어 토포필리아가 성공의 요인 역할을 해 왔 는가, 과학교육의 학습동기로서 적용할 수 있는가 등의 항목으로 구성하였다. 개방형 문항으로 토포필리아 함 양 교육을 위해 활용할 수 있는 지역의 교육자원을 추 천하도록 했다.

\section{IV. 연구 결과 및 논의}

\section{1. 아산 정주영의 토포필리아와 성공 요인}

정주영은 기회 있을 때 마다 고향의 산과 마을의 정 
경 등 어린 시절의 추억을 자주 언급하였다[12]. 고향 땅에 대한 강한 애착과 장소에 대한 애정은 국가와 역 사 인식의 굳건한 배경이 된다. 호주의 아란다 족은 '고 향 땅에 존재의 신경 섬유 일체까지 밀착되어 있다'고 생각한다[26]. 고향에 대한 사랑과 갈망, 어린 시절 고 향에서의 향수는 토템이 되는 조상 신화에서 끊임없이 나타나는 지배적인 모티브이다[1]. 아란다 족에게는 산 과 절벽, 샘물과 연못은 단순히 흥미롭거나 아름다운 볼거리가 아니다. 이는 자신의 존재가 여기에 이르도록 이끌어 준 조상들의 수공예품인 것이다. 호주나 미국의 인디언들처럼 자신들의 땅을 불법 점유한 백인들에 의 해 강제로 고향 땅을 떠나게 된 경우에는 더욱 강렬한 토포필리아가 형성된다. 어린 시절에 고향을 떠났던 정 주영 회장의 일생에서 토포필리아는 강렬한 성공의 동 기이자 삶의 원동력으로 작용했다. 정주영의 자서전 '시 련은 있어도 실패는 없다'에서 이야기의 시작은 다음과 같은 고향 마을에 대한 소개로부터 시작한다[12].

내 고향 송전의 아산 마을.

안변역에서 동해 북부선에 연결된 기차를 타고 다시 남쪽으로 달리면 차창 서편은 울창한 삼림에 덮힌 태백산맥이,

동편으로는 쪽빛 동해가 무한하게 펼쳐진다. 백사장과 하늘을 가릴 만큼 높이 자란 송림 사이로

양옥 별장들이 띄엄띄엄 보이기 시작한다.

해당화가 넓고 길게 이어진 송전 해수욕장이다. 여기서 도보로 한 시간 반쯤 가면 감나무 숲에 싸인 내 고향 아산 마을이다.

고향을 떠난 지 60 년이 더 지나서도 정주영은 고향의 모습을 눈 앞에 펼쳐 보는 듯이 묘사하고 있다. 일제하 에서 어려운 시절을 보내면서 가난이 싫어 어쩔 수 없 이 고향을 떠나야 했던 정주영으로서는 고향에 대한 아 쉬움과 애틋함이 특별할 수 밖에 없다. 특히 그는 아버 지와 함께 새벽별을 보며 소를 몰고 밭으로 나가 일을 하고, 저녁별을 보며 집으로 돌아오던 고향의 어린 시 절을 자주 회상하고 있다[13]. 지독하게 가난했던 고향 에서 3 번의 가출을 시도하였고, 소판 돈 70 원을 훔쳐서
17살의 나이에 고향을 영원히 떠나온 정주영에게 토포 필리아는 금의환향이라는 소망과 함께 강력한 삶의 원 동력이었고, 성공의 동기였을 것이다.

유년의 기억 속에 투영된 장소와 공간의 추억은 개인 에게 행복한 낙원의 형태로 강렬한 애착과 그리움을 불 러일으키는 토포필리아를 형성한다[9]. 자신의 지난 과 거를 회상 또는 기억할 때 그 자신의 구체적인 체험이 깃들어 있는 장소와 구체물은 기억의 주된 초점이자 핵 심적인 동기유발 요인이 될 수 있다. 정주영에게 있어 서는 장소로서의 고향과 구체물인 소가 그 역할을 하고 있다. 유년기는 시대성이나 역사의식, 학문 등에 의한 영향을 받기 이전의 시기로서 직접 보고 느낀 그대로의 순수함이 행복하고, 즐거운 정서로 자리 잡는다. 따라서 지나간 유년기는 되돌아갈 수 없는 낙원이고, 유년기의 토대를 이룬 공간 역시 다시 형성될 수 없는 낙원으로 기억되는 것이 일반적이다[51]. 그러므로 유년기의 주 요 소재지였던 고향의 경우, 집의 이미지처럼 따뜻한 안식처의 느낌을 주며 지속적인 애착과 그리움의 정서 를 불러오게 마련이다[11]. 고향에 대한 과거의 추억과 긍정적인 정서인 토포필리아는 현재를 통해 미래로 이 끌어가는 원동력이 된다. 일제 강점기에는 장소와 공간 에 관한 토포필리아가 더 폭넓게 다루어질 여지가 크 다. 아란다 족처럼 자신의 의지에 반하여 고향을 강제 로 떠나야 했던 힘들고 어려웠던 시절의 정서는 더 강 렬한 토포필리아를 형성하게 된다. 정주영의 고향과 소 에 대한 토포필리아는 성공의 동기요인이 되었으며 1998년에 소 1,001 마리를 이끌고 휴전선을 넘어 금의 환향하는 원동력이 되었다. 손광은(2001)은 다음과 같 이 정주영의 토포필리아로서 소의 역할과 그의 성공 스 토리를 노래하였다[14].

소 한 마리 그 빚을 되돌려 갚으러

오십년 막힌 고향 뚫고 가는 황소 소떼몰이 목동이 되어 방북 길까지, 음메, 음메, 메아리친 소떼를 몰고 하늘아래 천지에 소떼울음 메아리 감으며 감으며 갔다.

경영자의 의사결정 행동은 성장하면서 형성된 경험 
과 인지적, 가치적 특성을 반영하듯이[52], 정주영은 자 신이 갖는 열망과 그 열망에 이르기 위한 원인과 결과 간의 신념에 의해 영향을 받았다. 인간이 갖는 열망은 개인적인 가치 특성을 의미하며 대부분 어린 시절의 토 포필리아가 강한 영향력을 행사하고, 이를 이루기 위한 원인과 결과 간의 신념은 인지적 과정을 포함한다. 경 영자의 가치 지향과 원인, 결과에 대한 신념은 경영자 가 경영과 관련된 사건에 집중하고 이해하게 만드는 개 념의 틀로 작용하므로 경영자의 의사결정 과정에서 직 접적인 영향을 미칠 수 있다[15]. 정주영 회장의 의사결 정 행동 특성은 직관과 전체성, 맥락을 중요시함으로서 예감이나 육감, 비젼, 기업의 성공 가능성에 대한 느낌 등을 중요하게 생각하였다. 이러한 유형의 경영자는 보 통 창업형 기업인의 특성을 갖는다[53][54]. 정주영은 유연성과 상호조정, 비구체성, 비공식성에 가치 기반을 두는 창업형 기업인의 특성을 갖고 있으며 더불어 냉철 한 과단성과 판단력을 갖는 경영자였다. 이러한 특성을 갖게 된 배경에는 어린 나이에 맨손으로 사업을 시작하 며 겪었던 경험과 고향에서 형성된 긍정적 정서로서의 토포필리아가 큰 역할을 하였다.

\section{2. 드보르작의 토포필리아와 유모레스크}

인간의 감성은 다른 감각으로 전이될 수 있다는 공감 각에 주목하면, 긍정적 정서와 토포필리아는 음악에서 도 중요한 역할을 할 수 있다. 공감각(synesthesia)이란 '함께(syn)' 와 '감각(aisthesis)'의 합성어로서 감성을 잘 환기시켜 주는 음악적 감각이 공감각적 감성의 구조
화를 통해 색상이나 향기 등 새로운 지각으로 전이될 수 있음을 의미한다[16]. 즉 공감각은 소리를 들으면서 색을 느끼거나 색을 보면서 소리를 느끼는 것과 같이 2 개 이상의 감각이 동시에 느껴지는 것이다. 환경에서 받는 물리적 자극을 탐지하여 신경 신호로 변환시키는 과정을 '감각(sensation)'이라고 하면, 감각을 선택하여 느끼게 하는 것을 '지각(perception)' 이라고 한다. 공감 각은 감각의 한 수용 세계에 자극이 주어졌을 때 직접 감각 계통에 따르는 반응 외에 다른 감각 계통의 감성 반응을 불러일으키는 현상이라고 할 수 있다[55]. 이는 여러 감각들이 서로 감성 형성 작용과 다른 감각 유도 를 동시에 수용, 융합하여 다른 감성과 긍정적 정서를 일으킨다고 할 수 있다. 즉 귀를 자극하면 소리와 함께 시각적 색상도 느낄 수 있고, 긍정적인 정서와 함께 다 양한 공감각으로서 토포필리아를 형성한다. 소리와 같 은 음악적 자극은 감정적 수용과 이입을 통해 토포필리 아를 형성할 수 있다. 어린 시절에 들었던 음악적 자극 으로서 특정한 소리는 오감의 상호작용으로 정화 기능 을 담당한다. 시각과 청각 반응을 공유함으로 시각적인 것을 음악적인 것으로, 음악적인 것을 시각 예술로 표현 할 수 있으며 칸딘스키나 클레, 들로네 같은 화가들은 음악적 영감을 화폭에 담았고, 작곡가 쿤테, 슐러, 쉰베 르크, 스크리아빈은 색과 빛, 그림에서 영감을 받아 음 악으로 표현하였다[17][18][56]. 루치아노 파바로티는 악 보를 볼 때 음표를 색으로 인지하면서 음악을 그렸다고 하며, 노벨물리학상 수상자인 리처드 파인만은 수학 방 정식을 색깔로 구별하여 그림으로 수식을 표현하였다.

어린 시절에 형성된 음악적 자극으로서 소리의 공감

\section{Humoresque}

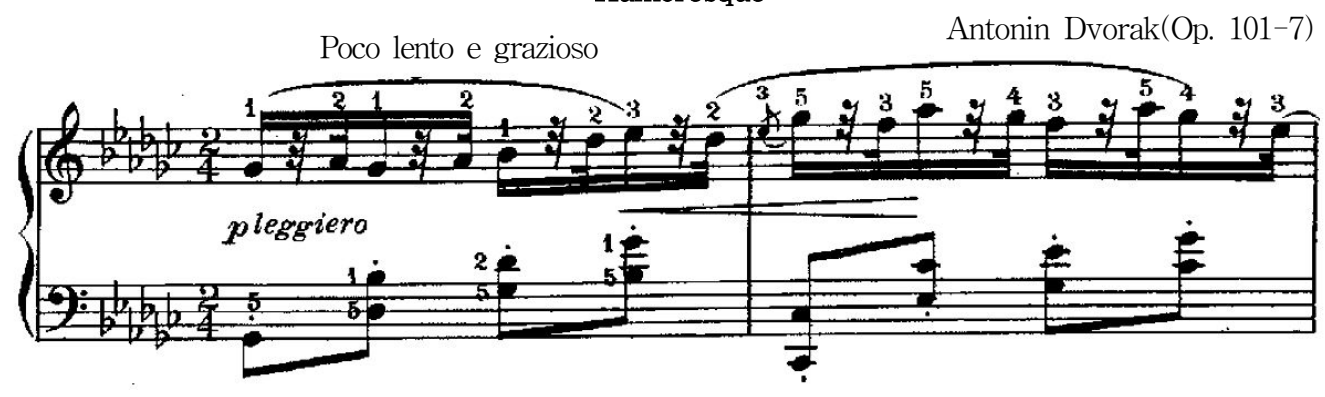

그림 1. 유모레스크(Op.101-7) 주선율 악보 
각과 토포필리아가 예술로 승화된 사례로 체코 음악가 드보르작의 '유모레스크(humoresque)'를 들 수 있다. 드보르작(Dvorak, A., 1841-1904)은 19세기 낭만파 음 악을 대표하며 민족주의적 성향을 지닌 음악가로 불리 운다. 그는 소박한 정서가 묻어나는 음악을 주로 작곡 하면서 인생을 긍정적으로 보고 고향에 대한 향수와 희 망, 기쁨을 주는 음악을 주로 창작하였다[19]. 드보르작 은 16 세에 고향을 떠나 프라하에서 음악을 전공하면서 떠나온 고향과 부모님에 대한 그리움, 향수 등이 어린 시절의 기억에 크게 자리 잡았다. 몰다우 강가의 조그 만 시골마을이었던 그의 고향은 미쟈르 족의 민요가 정 서적 바탕을 이루고 있으면서 식민지 국민으로서 어려 움과 배고픔을 가득 담고 있는 곳이었다. 그는 프라하 에서 부모님과 고향이 그리울 때마다 기차역에 가서 기 차소리를 들었고, 가만히 귀 기울이면서 고향을 회상하 며 토포필리아를 형성하였다. 그는 음악가가 되지 않았 다면 기차 기관사가 되었을 것이라고 말할 정도로 기차 와 기차 소리에 집중했다. 이러한 어린 시절의 향수와 영감, 자연에서 얻은 풍부한 정서, 보헤미야 민요의 영 향 등이 그의 작품에서 기반을 이루고 있다[19][20]. 드 보르작은 1892년부터 뉴욕의 내셔널 음악원장으로 초 청받아 미국에 체류하게 되는데, 대도시 뉴욕에서 쉽게 동화되지 못했고, 고향에 대한 향수가 더욱 강렬해졌다.
그의 고향에 대한 그리움과 토포필리아는 예술로 승화 되면서 고향을 잃고 고통 받고 있는 흑인의 민요와 영 가, 사라져 가는 인디언의 음악에 더욱 관심을 갖게 하 였다[19]. 드보르작에게 토포필리아는 이전과 다른 새 로운 작품 세계를 개척하는 동기를 주었다. 불후의 명 작 현악사중주 12 번 '아메리카'는 조국 체코에 대한 견 딜 수 없는 그리움의 표출이었으며 새로운 음악적 소재 를 융합하여 교향곡 제9번 '신세계로부터'도 완성할 수 있었다. 특히 소품 '유모레스크(Op.101)'는 그의 소박한 감수성과 고향에 대한 향수, 어린 시절의 기차소리 등 으로 이루어진 토포필리아가 공감각의 예술로 승화된 작품이다. 유모레스크의 주선율 리듬이 어린 시절 토포 필리아로 기억되는 기차소리와 얼마나 유사성이 있는 지 알아보기 위해 유모레스크의 도입 부분 주선율[그림 1]과 $70 \mathrm{~km} / \mathrm{h}$ 의 속도로 달리는 기차소리를 분석했다.

기차소리와 유모레스크의 파형과 주기를 분석하기 위해 음향 분석 프로그램인 ‘Cool Edit Pro 2.1' 을 사용 했다. 레일의 이음매 부분에서 규칙적으로 덜컹거리는 기차소리와 유모레스크의 주선율 리듬은 2.40 초 주기로 4 개의 파형이 반복되며 그 주기가 일치했다[그림 2] (가)와 (나). 두 소리를 믹스해 보면 2.43초 주기로 4개 의 파형이 반복되면서 기차소리와 유모레스크 주선율 리듬은 아름다운 하모니를 형성하였다[그림 2](다). 어

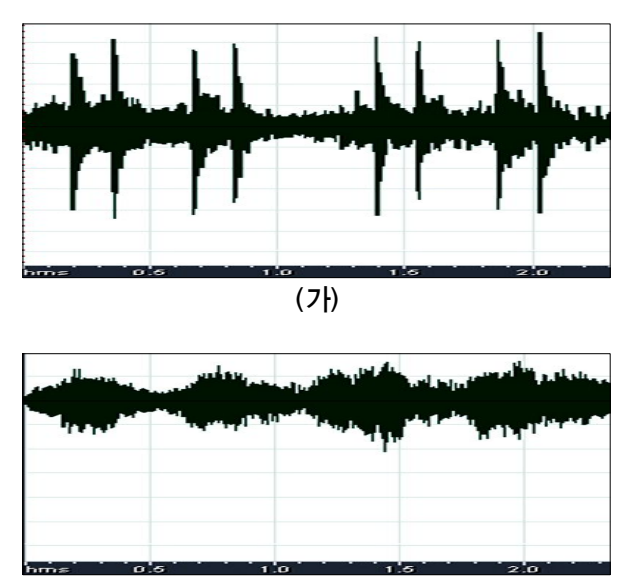

(나)

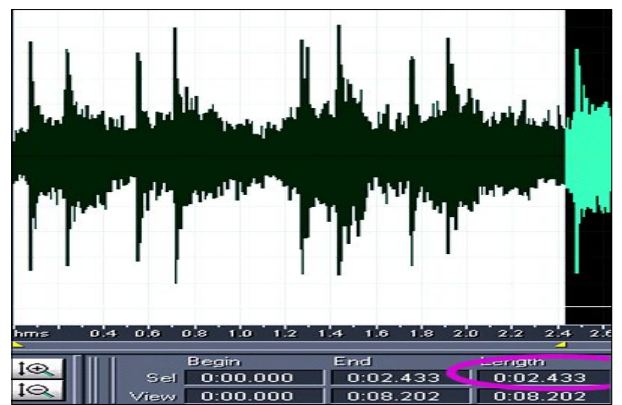

(다)

그림 2. 기차소리와 유모레스크 파형 분석. (가) 기차소리 $(70 \mathrm{~km} / \mathrm{h}$ ) (나) 유모레스크 주선율 (다) 기차소리 와 유모레스크 믹스 
린 시절에 들었던 기차 소리가 리듬이 되어 드보르작의 토포필리아를 통해 멜로디로 창작되면서 유모레스크가 되었음을 확인할 수 있었다. 유모레스크와 기차의 레일 소리처럼 동일한 형태의 리듬과 가락이 반복되는 오스 티나토(ostinato)는 듣는 사람으로부터 예민한 감수성 과 향수를 불러 온다[21]. 그러므로 유모레스크를 듣는 사람들은 고향의 기차소리를 연상하게 되면서 행복했 던 어린 시절의 아름다운 장소를 떠올리게 된다.

자연에서 리듬은 매우 흔한 것으로 어린 시절 들었던 엄마의 심장 소리, 자연의 소리 등이 토포필리아와 합 쳐지면서 리듬을 구성한다. 리듬(rhythm)이란 '흐름'이 나 '움직임'을 의미하는 그리스어의 'rhythomos'에서 유래된 것으로 시간적으로 움직이는 모든 것을 질서 있 게 조정하는 것을 말한다[22]. 음들의 지속시간과 빈도, 그것이 울리는 데 있어서의 규칙성과 불규칙성이 한 악 절의 리듬을 결정한다. 어머니의 심장 박동소리를 열 달 동안 듣게 되면 태아는 어머니의 정서에 따른 심정 적 리듬, 빠르고 느린 걸음, 움직임, 언어 등을 비물리적 인 방법으로 전달 받으면서 여러 가지의 리듬을 직, 간 접적으로 체험하게 된다. 태어나서도 어머니와 아버지 라는 시각적 2 박자 리듬 등을 생활 속에서 체감하며 유 아는 기기, 걷기, 뛰기 등의 움직임을 통하여 무한한 리 듬을 만들어 나가고 체험하게 된다. 이러한 리듬은 선 율, 화성과 함께 음악의 3요소로 불리는데 화성이나 선 율이 없어도 리듬만으로 음악을 구성할 수 있다는 점에 서 음악의 요소 중에서 리듬이 가장 중요하다고 말할 수 있다[22][57]. 무용이나 문학의 시 등은 모두 리듬 없 이는 성립될 수 없는 예술이다. 즉 리듬은 우리들의 생 활 속에 있는 자연현상에도 항상 존재하는 것으로서 일 출과 일몰, 계절의 변화, 심장박동, 호흡, 걷기 등도 조 직된 시간적 운동인 리듬에 그 기초를 두고 있다. 이와 같이 리듬은 초음악적 존재이며 인간의 일상생활에도 근원적인 역할을 하고 있는 것이다. 이러한 리듬 위에
멜로디가 얹혀 지면 음악이 되는 것이고, 자연에서 조 화와 원리를 찾다보면 과학이 되는 것이다. 우주로부터 오는 하모니와 행성 운행의 리듬을 찾고자 노력한 케플 러는 자신의 세 번째 법칙을 '세상의 하모니(The hormonies of the world)' 로 발표하였다. 여기서 그는 행성 운동에서 찾아 볼 수 있는 질서와 아름다움 그리 고 그것을 기술할 수 있는 수학적 공식을 음악적 하모 니라는 개념에 포함시켰다. 그는 행성 운동에 관한 조 화의 법칙을 발견하고, '이 소리들의 화음으로 인간은 영원을 한 시간 안에 연주할 수 있게 되었다’라고 표현 했다[58]. 리듬은 마음에서 나온다[57]. 리듬이란 관찰 대상의 많은 것들에서 식별 가능한 덩어리로 개념화하 는 것으로서 음악뿐만 아니라, 모든 종류의 인식에 있 어서 기본이 되는 요인이라고 할 수 있다. 드로브작의 어린 시절에 형성된 고향과 자연에서의 토포필리아가 긍정적 정서로 작용하여 음악적인 리듬으로 표출되었 고, 멜로디와 하모니를 이루면서 유모레스크로 승화될 수 있었다. 그래서 드보르작의 유모레스크를 들을 때 더 많은 사람들이 공감하고 어린 시절의 향수를 떠올리 며 감동할 수 있는 것이다.

\section{3. 토포필리아 함양을 위한 교육자원 분석}

\section{1 전북지역의 토포필리아 교육자원}

조상들의 지혜와 예술가의 패러다임 전환 과정을 재연 하고 감성적으로 체험할 수 있는 토포필리아 계발에 활 용될 교육자원 분석을 위해 전북지역의 중등학교 교사와 과학교육 전공 교수에게 설문조사를 실시했다[표 1].

대부분의 설문 대상자들은 토포필리아가 동기부여 측면에서 긍정적인 영향이 있었음을 경험하였고, 학습 동기로서 작용할 수 있는 가능성에 대해 긍정적인 견해 를 보였다. 개인적인 경험으로서 어린 시절의 토포필리 아가 삶을 살아가는데 동기 부여를 해주는 역할을 하였

\section{표 1. 토포필리아를 함양할 수 있는 전북 지역의 교육자원 설문 결과}

\begin{tabular}{|l|l|l|}
\hline \multicolumn{1}{|c|}{ 설문 내용 } & \multicolumn{1}{|c|}{ 조사 방법 } & \multicolumn{1}{c|}{ 결과 } \\
\hline 토포필리아와 동기 역할(개인 경험) & 리커트 척도 & $4.70(0.48)$ \\
\hline 토포필리아와 학습동기(교육 가능성) & 리커트 척도 & $4.50(0.53)$ \\
\hline 토포필리아 교육자원 제안 & $\begin{array}{l}\text { 과학/예술/전통/문화/자연 등에서 5개 교육자원 } \\
\text { 제안(서술형) }\end{array}$ & $\begin{array}{l}\text { 한옥마을, 비빕밥, 마이산, 최북, 모악산, 영 } \\
\text { 화, 만경강 등 }\end{array}$ \\
\hline
\end{tabular}


는지에 대한 설문 조사에서 대부분의 응답자는 리커트 척도 4.70점(5단계 척도)의 긍정적 평가를 내렸고, 삶의 원동력으로서 토포필리아의 역할에 대해서도 적극적으 로 동의했다. 또한 토포필리아가 학습자에게 학습동기 로 작용할 수 있을지에 대한 가능성에서도 높은 긍정적 평가(4.50점)를 했다. 전북지역의 과학과 예술, 전통, 자 연 등에서 학생들에게 토포필리아를 교육할 수 있는 교 육자원으로 한옥마을과 전주 비빔밥, 마이산을 가장 많 이 제안했고, 최북과 모악산, 영화거리, 만경강 등도 제 시되었다.

우리 고장의 장소와 구체물들을 교수-학습의 장으로 끌어들여서 의미를 찾고 스토리를 만들며 의미로서의 기억을 갖는 장소를 만들어 갈 수 있도록 하는 공감각 의 체험 활동의 기회를 제공해야 한다. 토포필리아 함 양 프로그램은 학생들이 살고 있는 터전으로서의 장소 에 대한 소속감과 애향심, 자부심을 갖게 하고 우리 것 에 대한 가치를 재인식하면서 새로운 내적동기 역할을 할 수 있다. 동시에 교육 문화 프로그램으로서의 역할 도 더해진다면 학생들이 과학과 예술, 문화에 더 많은 관심과 흥미를 가질 수 있고 과학 탐구의 과정이 곧 감 성적 체험의 장이 되어 지적인 희열과 몰입을 체험할 수 있을 것이다.

\section{2 토포필리아 융합교육을 위한 학습 소재}

학생들에게 토포필리아를 함양시킬 수 있는 융합교 육을 위한 교육자원 조사와 교육과정 검토를 통해 중등 학교에서 창의적 체험활동이나 방과후학교 활동으로
수업에 활용할 수 있는 토포필리아 교육자원을 제안하 면 [표 2]와 같다.

어린 시절에 뛰놀던 장소와 공간은 세월이 지나면서 긍정적 정서로서 토포필리아를 형성한다. 전북 진안의 마이산은 말의 귀 모양처럼 생겨서 유명하고, 세계적으 로도 큰 규모의 역암층으로 알려져 있다. 또한 탑사를 이루고 있는 기이한 돌탑들과 거꾸로 솟아오르는 역고 드름이 나타나는 곳으로도 잘 알려진 관광지이다[25]. 학생들이 우리 고장의 마이산을 탐방하며 지질과 역고 드름 등을 관찰하고, 탐구를 통해 그 가치와 의미, 과학 적 원리 등을 밝혀내며 동시에 마이산 홍보대사 역할도 해봄으로써 애향심과 토포필리아를 형성해 갈 수 있는 교수-학습 프로그램 개발이 필요하다.

삶의 터전이었던 집과 특정 장소는 토포필리아가 형 성될 수 있는 결정적인 요인이다. 전주 한옥마을은 한 국적인 슬로시티의 전형으로서 현대의 노마드적으로 살아가는 학생들에게 토포필리아를 형성하게 할 수 있 는 좋은 교육자원이다. 한옥의 과학적 원리를 창의적 설계와 제작 활동이 포함된 한옥마을 체험 프로그램을 통해 감성적으로 확인해볼 수 있을 것이다. 또한 한옥 에 담겨 있는 선인들의 지혜를 현대 과학 기술로 재해 석해보며 한옥의 가치와 의미를 새롭게 인식함으로서 우리 고장에 대한 자긍심과 애향심을 고취시킬 수 있을 것이다.

무주 출신의 화가 최북(1720-1786?)은 잘 알려져 있 지 않으나, 조선 후기 미술가인 정선과 심사정, 강세황 등과 교류하며 표훈사도, 공산무인도 등을 남겼다. 최북

\section{표 2. 과학 체험활동으로 개발 가능한 전북지역의 토포필리아 교육자원}

\begin{tabular}{|c|c|c|c|}
\hline 교육자원 & 내용 & 학생 활동 & 학습 주제 \\
\hline $\begin{array}{l}\text { 마이산 } \\
\text { 역고드름 }\end{array}$ & $\begin{array}{l}\text { 전북 진안군 마이산의 신비한 역고드름 현상과 역암층(타포니 구조) } \\
\text { 의 과학적 원리를 탐구. 창의적 탐구와 감성적인 체험 프로그램 개 } \\
\text { 발 }\end{array}$ & $\begin{array}{l}\text { 홍보대사가 되어 마이산 관광 홍보, } \\
\text { 융합교육을 통해 지역 발전 기여, 애 } \\
\text { 향심 함양 }\end{array}$ & $\begin{array}{l}\text { 역고드름 실험, 역 } \\
\text { 암층과 파포니 구 } \\
\text { 조 }\end{array}$ \\
\hline 전주 한옥마을 & $\begin{array}{l}\text { 한국적인 슬로시티 ㅈㅓㅓㅈㅜ 한옥마을에서 우리 민족의 슬기와 과학적 } \\
\text { 원리, 한옥의 건축학적 창의-설계를 체험할 수 있는 토포필리아 계 } \\
\text { 발 프로그램 }\end{array}$ & $\begin{array}{l}\text { 전통 한옥의 건축 기법을 직접 설계- } \\
\text { 제작해 보는 창의 체험과 한옥마을을 } \\
\text { 탐방하며 전통과학을 현대의 과학 기 } \\
\text { 술로 해석하고 교육하여 감성적 체험 }\end{array}$ & $\begin{array}{l}\text { 한옥의 창의적 건 } \\
\text { 축 설계, 온돌의 } \\
\text { 과학, 숨쉬는 한옥 }\end{array}$ \\
\hline 최북의 예술 & $\begin{array}{l}\text { 무주 출신 화가 최북의 삶과 그림을 스토리텔링과 감성적 체험 활동 } \\
\text { 으로 재발견. 지두화법을 통해 최북의 예술적 감성과 과학 원리를 } \\
\text { 체험하고 배울 수 있음 }\end{array}$ & $\begin{array}{l}\text { 예술가 특강과 최북 미술관 탐방, 체 } \\
\text { 험활동을 통해 최북의 삶과 예술을 공 } \\
\text { 감하면서 감성 체험과 토포필리아 형 } \\
\text { 성 }\end{array}$ & $\begin{array}{l}\text { 예술가 특강, 풍설 } \\
\text { 야귀인도 스토리 } \\
\text { 텔링, } \\
\text { 지두화법 재현 }\end{array}$ \\
\hline 고추장 & $\begin{array}{l}\text { 전주 비빔밥에 들어가고, 임금님 진상품이었던 고추장에 들어 있는 } \\
\text { 선인들의 지혜와 과학 원리를 체험. 고추장을 활용하여 퓨전음식을 } \\
\text { 만들어 보면서 고추장을 새로운 의미 기억으로 체험하게 함 }\end{array}$ & $\begin{array}{l}\text { 고추장에 대한 감성 체험과 자랑할 만 } \\
\text { 한 우리나라 전통음식으로서 글로컬 } \\
\text { 토포필리아 형성 }\end{array}$ & $\begin{array}{l}\text { 고추장 과학 원리 } \\
\text { 글로컬 고추장 감 } \\
\text { 성체험 }\end{array}$ \\
\hline
\end{tabular}


은 붓으로 먹고사는 사람이라는 뜻의 호생관이라는 호 를 가졌으며 출신이 중인으로 비천하여 스스로를 칠칠 이라 불렀고 기행과 괴짜의 삶을 살았다[23]. 그림을 강 요하는 양반의 위협에 '남이 나를 버리기 전에, 내 눈이 먼저 나를 저버린다'며 스스로 한쪽 눈을 찔러 저항하 였고, 성품과 행동이 서양화가 고흐와 비슷하다고 하여 ‘한국의 고흐' 라고도 불린다. 최북은 어린시절 덕유산 과 구천동 계곡에서 추위와 배고픔, 넘을 수 없는 신분 의 벽 등을 느끼면서 토포필리아를 형성했다. 이러한 토포필리아는 그의 작품에 녹아들어서 '풍설야귀인도' 를 그릴 수 있었다. 자연에 더 가까이 다가가기 위해 손 가락으로 그림을 그리는 지두화법으로 먹의 농담을 조 절하여 다채롭게 표현하였으며 손가락의 강약을 조절 하여 힘과 생동감을 느끼게 하였다[24]. 잘 알려지지 않 은 우리 고장의 예술가 최북을 재발견하고, 그의 예술 적 가치와 삶에 대한 감성적 체험을 통해 학생들도 최 북이 느끼고 그가 가졌던 토포필리아를 공감하고 체득 할 수 있는 교수-학습 프로그램을 개발해야 한다.

어린 시절에 자주 먹던 음식과 맛에 대한 추억은 토 포필리아를 형성할 수 있는 좋은 소재이다. 고추장은 우리나라의 대표적인 장류로 매일 접하는 친숙한 음식 이지만, 학생들은 고추장이 갖고 있는 숨은 가치와 조 상들의 지혜에 대해서는 잘 알지 못하고 있는 것이 현 실이다. 이에 고추장을 이용해 청소년들에게 토포필리 아를 형성시킬 수 있는 감성 체험 프로그램 개발이 필 요하다. 전주 비빔밥에 들어가는 고추장을 만들어 보는 감성적 체험과 고추장을 이용한 퓨전 음식 '김치 고추 장 파스타'를 직접 요리해보는 것 등을 통해 고추장 속 에 숨겨진 선인들의 지혜와 고추장이 포함된 요리가 글 로컬 한식으로 발전할 수 있도록 세계화 전략을 구상해 보는 새로운 도전도 해볼 수 있다.

\section{V. 결론 및 제언}

고향의 장소와 구체물에 대한 리추얼과 긍정적인 정 서로 이루어진 토포필리아는 중요한 삶의 동기 요인이 될 수 있다. 본 연구에서 토포필리아의 학습동기 역할
과 정주영, 드보르작에 대한 기록연구, 음향 분석, 토포 필리아 함양 교육에 활용될 교육자원 분석을 통해 다음 과 같은 결론을 얻었다.

첫째, 청소년기에 일상에서 접하는 자연과 삶의 근거 인 집과 장소 등 구체물에서 경험하는 다양한 기억들은 학습과 정서적 반응, 의미부여의 과정을 거쳐 토포필리 아를 형성하게 된다. 토포필리아는 경험하는 순간, 그 즉시 발생하는 것이 아니라 시간이 지남에 따라 그 장 소의 특별한 의미와 가치를 인식하게 되는 과정에서 점 진적으로 축적되며 학습되어지는 긍정적 정서라고 할 수 있다. 학습자의 긍정적 정서는 학업성취와 문제해결, 창조적 정보처리, 효율적인 의사결정 능력과 과제의 집 착력을 향상시키는 데 크게 기여한다. 이에 학생들이 살고 있는 도시와 지역에 대한 가치를 인식하게 하고 의미를 부여할 수 있는 교육 프로그램이 필요하다. 특히 한 곳에 정착하지 못하고 신유목민으로 살아가야 하는 현대의 학생들에게 도시와 지역, 자연과 경관, 문화, 예 술을 교육자원으로 토포필리아를 함양할 수 있게 해야 한다. 자연과 공간에서의 미학적인 쾌감과 감성적인 체 험은 강렬하지만 순간적이어서 과학적 호기심이나 관 심, 체계적으로 안내된 교육 활동 등과 결합해야 오랫동 안 지속될 수 있고 긍정적 정서로 작용하여 학습동기로 자리 잡을 수 있다. 아직 미학의 공식적인 규범에 물들 지 않은 청소년들에게 지역의 교육자원을 활용하여 토 포필리아를 형성할 수 있게 함으로서 어른이 되었을 때 아름다운 추억으로 자리매김 될 수 있도록 해야 한다. 둥지가 있는 새가 더 멀리 날 수 있는 것처럼 토포필리 아가 학생 개인의 강력한 정서적 유대감으로 작용하여 삶의 원동력이자 학습의 동기 역할을 할 수 있다.

둘째, 어린 시절에 형성된 토포필리아가 성공의 원동 력이며 예술의 혼으로 작용한 사례를 분석했다. 기록연 구를 통하여 정주영의 소에 대한 애착과 고향의 그리움 이 어린 시절에 강하게 형성되었음을 확인했다. 그의 경영철학과 의사결정 유형은 직관과 전체성, 맥락을 중 요시함으로서 맨손으로 사업을 일으키며 가졌던 예감 과 비전, 기업의 성공 가능성 등을 중시하는 창업형 기 업인의 특성을 가졌다. 이는 정주영의 어린 시절에 고 향 아산 마을에서 형성된 토포필리아가 중요한 역할을 
했다. 유년의 기억 속에서 투영된 장소와 공간의 추억 은 행복한 낙원의 형태로 강렬한 애착과 그리움을 일으 키는 토포필리아를 형성한다. 정주영에 있어서 장소로 서의 고향과 구체물로서의 소가 그의 성공 동기 요인이 되었다. 체코의 낭만파 음악가 드보르작이 작곡한 유모 레스크는 시골 고향에 대한 소박한 감수성과 향수 그리 고 어린 시절의 토포필리아로 기억되는 기차 소리가 공 감각의 예술로 승화된 작품이다. 인간의 감성은 다른 감각으로 전이되어 표현될 수 있다는 공감각에 주목하 면 토포필리아는 음악에서도 중요한 역할을 할 수 있는 데, 어린 시절에 들었던 기차 소리 같은 음악적 자극은 오감의 상호작용과 시공간의 리추얼, 긍정적 정서 등이 결합하여 유모레스크와 같은 명작을 작곡할 수 있었다. 16 세에 고향을 떠나 프라하에서 살면서 더욱 강력해진 토포필리아는 어린 시절의 향수와 영감, 자연에서 얻은 풍부한 정서, 몰다우 강가의 민족적 정서가 더해지면서 유모레스크로 승화된 것이다. 유모레스크의 주선율 리 듬이 토포필리아로 기억되는 기차 소리와 파형과 주기 가 일치했다. 특히 두 소리를 믹스해 보면 2.43초 간격 으로 리듬과 가락이 반복되는 오스티나토로 조화를 이 루면서 듣는 사람으로부터 예민한 감수성과 향수 등 다 양한 정서를 불러일으킨다.

셋째, 과학 교사와 교육 전문가들의 설문 조사를 통 하여 전북 지역의 전통과 음식, 자연 등 다양한 교육자 원으로 학생들에게 토포필리아를 함양할 수 있는 학습 소재를 분석하였다. 조사 대상자들은 토포필리아가 삶 의 원동력이 될 수 있으며 학습동기(4.5점, 리커트 5단 계 척도)로 작용할 수 있다고 하였고, 학습소재로서 마 이산과 한옥마을, 고추장, 무주 출신의 화가 최북을 제 안했다.

현대와 같이 장소성이 약화된 문화적 조건 속에서 청 소년들은 장소 감각이나 공간 정서, 전통 음식과 가옥 등에 대한 리추얼과 토포필리아가 형성될 수 있는 기회 를 점차 잃어가고 있다. 특히 요즘 학생들은 입시교육 과 인지학습에 지쳐 있어서 더욱 감성적 체험활동과 인 성교육이 필요하다. 본 연구에서 제안된 교육자원을 활 용하여 구체적인 토포필리아 함양을 위한 수업 방법이 후속 연구로 이루어지기를 제언한다.

\section{참 고 문 헌}

[1] 조은숙, "송기숙 소설의 토포필리아 연구", 현대문 학이론, 제46권, pp.273-295, 2011.

[2] 김정운, "관계적 정서와 문화적 정서", 한국심리학 회지, 제20권, 제2호, pp.389-407, 2001.

[3] 장일구, 경계와 이행의 서사 공간, 서강대학교출 판부, 2011.

[4] 김주환, 신우열, 함정현, "행복은 우리를 통하게 한다: 긍정심리학 관점에서 커뮤니케이션 이론 다 시 보기", 커뮤니케이션 이론, 제 5 권, 제 1 호, pp.86-122, 2009.

[5] 김성일, "뇌기반 학습과학: 뇌과학이 교육에 대해

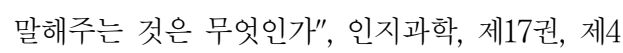
호, pp.375-398, 2006.

[6] 김은주, 박해정, 김주환, "교육에서의 긍정적 감성 의 역할", 감성과학, 제 13 권, 제 1 호, pp.225-234, 2010.

[7] 김민경, "예비초등교사의 학습동기 전략에 관한 연구", 초등수학교육, 제6권, 제2호, pp.55-64, 2002.

[8] 신민희, "자기조절 학습환경이 학습성취와 동기에 미치는 영향", 교육공학연구, 제 14 권, 제 3 호, pp.177-204, 1998.

[9] 신재은, "유년의 기억 속에 투영된 공간 수사학", 현대문학연구, 제28권, pp.305-335, 2006.

[10] 김형국, 땅과 한국인의 삶, 나남출판사, 1999.

[11] 김정아, "이문구 소설의 토포필리아", 문예시학, 제15권, pp.43-66, 2004.

[12] 정주영, 시련은 있어도 실패는 없다, 현대문화신 문사, 1992.

[13] 이홍, "뇌 활용 성향과 기업경영: 이병철 회장과 정주영 회장을 통한 탐험적 추론", 한국경영과학 회지, 제30권, 제 1 호, pp.105-128, 2005.

[14] 손광은, "초대시단: 노동자 아들 아산 정주영", 시와 시학, 제44권, pp.35-38, 2001.

[15] 이홍, "경영자 관점의 적합성과 경영자의 지배적 논리: 현대건설과 정주영 회자에 대한 사례", 경영 
학연구, 제27권, 제4호, pp.1091-1111, 1998.

[16] 유인하, "광고 음의 공감각에 의한 이미지와 색 지각 연구", 커뮤니케이션디자인학연구, 제 41 권, pp.82-95, 2012.

[17] 서영인, 음악의 공감각적 시각화 표현 연구, 한국 디자인학회 학술발표회 논문초록집, pp.204-205, 2004.

[18] 이진, 이승연, "융합인재교육 프로그램을 통해 배우는 공감각의 감성적 표현 연구", 한국콘텐츠 학회논문지, 제13권, 제9호, pp.448-454, 2013.

[19] 이상범, "촌놈의 아주 건전한 음악: 드보르작의 첼로 협주곡", 기독교사상, 제5권, pp.206-211, 2004.

[20] 김현종, "드보르작 교향곡 제9번 e단조 op.95의 연주론적 고찰", 음악과 민족, 제16권, pp.232-252, 1997.

[21] 권덕원, 석문주, 최은식, 함희주, 음악교육의 기 초, 교육과학사, 2008.

[22] 유덕희, 아동발달과 음악교육, 개문사, 1983.

[23] 유홍준, 화인열전1, 역사와 비평사, 2001.

[24] 국립전주박물관, 호생관 최북, 통천문화사, 2012.

[25] 윤마병, 김희수, 손정호, 양종우, “솟는 고드름의 형성과정에 관한 관찰, 실험 및 분석”, 한국지구과 학학회지, 제30권, 제4호, pp.454-463, 2009.

[26] Y. F. Tuan, Space and Place: The Perspective of Experience, University of Minnesota Press, 1977.

[27] Y. F. Tuan, "Topophilia, or sudden encounter with the landscape," Landscape, Vol.11, pp.29-32, 1961.

[28] OECD, Understanding the brain: The birth of a learning science, Center for educational research and innovation, 2007.

[29] J. G. Calson and E. Hatfield, Psychology of Emotion, Harcourt Brace Jovanovich, 1992.

[30] J. Reeve, Understanding motivation and emotion, John Wiley and Sons, 2009.

[31] B. L. Fredrickson, "What good are positive emotions," Review of General Psychology, Vol.2, pp.300-319, 1998.

[32] P. J. Carnevale and A. M. Isen, "The influence of positive affect and visual access on the discovery of integrative solutions in bilateral negotiation," Organizational Behavior and Human Decision Processes, Vol.37, pp.1-13, 1986.

[33] K., Kraiger, R. S. Billings, and A. M. Isen, "The influence of positive affective states on task perceptions and satisfaction," Organizational Behavior and Human Decision Processes, Vol.44, pp.12-25, 1989.

[34] C. D. Baston, J. S. Coke, F. Chard, D. Smith, and A. Taliaferro, "Generality of the glow of goodwill: Effecs of mood on helping and information acquisition," Social Psychology Quarterly, Vol.42, pp.176-179, 1979.

[35] A. M. Isen, "Success, failure, attention, and reaction to others: The warm glow of success," Journal of Personality and Social Psychology, Vol.15, pp.294-310, 1970.

[36] A. M. Isen and P. F. Levin, "Effect of feeing good on helping: Cookies and kindness," Journal of Personality and Social Psychology, Vol.21, pp.384-388, 1972.

[37] K. Oatley and S. Nundy, "The handbook of education and human development: New models of learning," teaching and schooling, Wiley-Blackwell, 1999.

[38] A. M. Isen, K. A. Daubman, and G. P. Nowicki, "Positive affect facilitates creative problem solving," Journal of Personality and Social Psychology, Vol.52, pp.1122-1131, 1987.

[39] A. M. Isen, M. M. Johnson, E. Mertz, and G. F. Robinson, "The influence of positive affect on the unusualness of word associations," Journal of Personality and Social Psychology, Vol.48, 
pp.1413-1426, 1985.

[40] H. A. Wadlinger and D. M. Isaacowitz, "The Experimental Manipulation of a Positive Visual Attention Bias," Emotion, Vol.8, pp.121-126.

[41] B. E. Kahn and A. M. Isen, "The influence of positive affect on variety-seeking among safe, enjoyable products," Journal of Consumer Research, Vol.20, pp.257-270, 1993.

[42] A. M. Isen and K. A. Daubman, "The influence of affect on categorization," Journal of Personality and Social Psychology, Vol.47, pp.1206-1217, 1984.

[43] B. Weiner, "An attributional theory of achievement motivation and emotion," Psychological Review, Vol.92, pp.548-573, 1985.

[44] C. E. Izard, The Psychology of Emotions, Plenum, 1991.

[45] R. N. Caine and G. Caine, Unleashing the Power of Perceptual Change: The Potential of Brain-Based Teaching, Association for Supervision and Educational Development, 1997.

[46] L. Corno and E. B. Mandinach, "The role of cognitive engagement in classroom learning and motivation," Educational Psychologist, Vol.18, pp.88-108, 1983.

[47] P. A. Ertmer and T. J. Newby, "The expert learner: Strategic, self-regulated and reflective," Instructional Science, Vol.24, pp.1-24, 1996.

[48] M. C. Schmitt and T. J. Newby, "Metacognition: relevance to instructional design," Journal of Instructional Development, Vol.9, pp.29-33, 1986.

[49] M. Csikszentmihalyi, Finding flow: the psychology of engagement with everyday life, Basic Books, 1998.

[50] F. C. Dane, Research Methods, California, Books/Cole Publishing Company, 1991.

[51] G. Bachelard, The Poetics of Space, Beacon
Press, 1994

[52] J. D. Thompson, Organizations in Action, McGraw Hill, 1967.

[53] B. Bird, "Implementing Entrepreneurial Ideas:

The Case for Intention," Academy of Management Review, Vol.13, pp.442-453, 1988.

[54] H. Mintzberg, "Strategy Making in Three Modes," California Management Review, Vol.16, pp.44-53, 1973.

[55] E. H. Gombrich, Art and illusion, Princeton University Press, 2000.

[56] K. Orlandatou, Synesthesia and art, Academy of music and theater of Hamburg, 2009.

[57] R. Jourdain, Music, the brain, and ecstasy, Avon Books, 1998.

[58] C. E. Sagan, Cosmos, Random House, 1980.

\section{저 자 소 개}

윤 마 병(Ma-Byong Yoon)

정회원

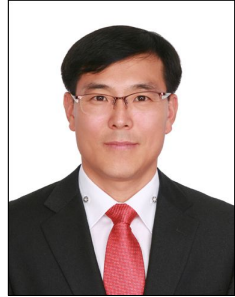

- 2010년 2월 : 공주대학교대학원 지구과학교육과 과학교육학 박사 - 2011년 3월 현재 : 전주대학 교 과학교육과 교수

<관심분야> : 과학교육, 교육 